\title{
POHŘBÍVÁNÍ NA MORAVĚ V 16.-18. STOLETÍ
}

\author{
MICHAELA KRÁLÍKOVÁ
}

\begin{abstract}
Abstrakt: Výsledky studia pohřebního ritu v novověku představuji zdroj informací o sociální struktuře tehdejši společnosti, o jejich postojich ke smrti a víre a v neposlední řadě o zvyklostech, které můžeme srovnávat s jevy jiných historických období. Na prozkoumaných novověkých hřbitovech na Moravě můžeme sledovat predevšim prvky katolického pohřebního ritu, nebot' toto náboženství bylo po téměr celé sledované období prednostně cirkví a státem diktováno. Pohřby jinověrců byly sice v určitých letech oficiálně tolerovány, avšak po mnoho let tito lidé pohřbívali tajně, předevšim po Obnoveném zřrizení zemském. Žil-li katolík přikladně a stejně tak zemřel, spočinul po smrti v posvěcené půdě hřbitova, v hrobě řádně označeném, většinou opatřeném životopisnými daty. Osoby sociálně výše postavené, církevni hodnostáři či majetní občané byli pohřbíváni s poctami a výpravnosti charakteristickou pro barokni dobu. Tito zemřeli nalezli místo svého odpočinku v rodinných hrobkách v kostele nebo hřbitovní kapli. Na Moravě se nacházi celá řada dokladů novověkých pohřbůs výbavou, které mohou vypovidat mnohé o těchto lidech a jejich životech.
\end{abstract}

Klíčová slova: novověk - smrt-pohřeb-hřbitov-kostel.

\section{Burials in Moravia in the 16th-18th Centuries}

Abstract: Results of the study of burial rites in the modern age present a source of information about the structure of the society and its attitudes to death and religion, as well as about customs that can be compared to the phenomena of other historical periods. Investigated modern-age graveyards in Moravia enable to study, in particular, the elements of Catholic funeral rites, as this religion was officially dictated by the church and the state throughout the observed period. Although funerals of those of different faith were tolerated in certain years, these individuals were usually buried in secret. If a person of the Catholic persuasion lived a virtuous life, they were buried in the consecrated ground of a cemetery, in a marked grave provided with biographical data. People of high social status, the clergy and the wealthy classes were buried with honours and pomp characteristic of the baroque period. Their resting places were in family tombs in churches or cemetery chapels. In Moravia there is multiple evidence of modern-age burials with grave goods bearing witness of the status of the deceased and their way of life.

Key words: modern age-death-funeral-graveyard-church.

V životě novověkého člověka hrála smrt velmi důležitou roli, stejně tak jako vše, co se smrtí souviselo, především pak samotný pohřeb. Smrt byla hluboce prožívána, platila za nezbytnost, na niž bylo lepší se předem připravit. Nejen smrt, ale i její okolnosti chtěl mít novověký člověk pod kontrolou, nebot' i to bylo důležité pro splnění podmínek „dobré smrti“ (k tematice umírání a smrti viz např. Zuber 1987; Ariès 2000; Král 2007, 7-22; Králíková 2007, 17-22).

V reformačním 16. století těžko hledáme zaběhlé pohřební tradice. O vztahu ke smrti a pohřbu nám leccos napovídá slabá, popř. chybějící pohřební výbava. Na jedné straně se zdá, že vlivem absence pohřební výbavy jsme informačně ochuzeni (a jsme závislí na dokladech, jež nám přináší dobové písemnosti), z druhého pohledu však můžeme vnímat toto období jako do určité míry popírající dosavadní pohřební kulturu a nevyhnutelně tolerující nárůst alternativních pohřebních praktik. Ty je potřeba dávat do souvislostí s konfesijními rozpory 16. i 17. století, popř. válečnými událostmi té doby a s tím související ekonomickou situací (doklady alternativních pohřbů najdeme v písemných zmínkách a na základě nich můžeme vysvětlit i některé nálezy pohřbů s netradičními prvky a na netradičních místech; blíže viz např. Unger 2002; Sterneck 2007). Náboženská nestabilita se v lidském vnímání projevuje jak snahou o zdůraznění sociálního postavení (pohřby šlechty se zbraní, šperky, řády) na jedné straně, tak zdůrazněním prostoty a jednoduchosti na straně druhé (prostý oděv, absence př́ídavků).

Po pobělohorských událostech, kdy nastalo období rekatolizace a protireformace, se začaly pohřební zvyklosti ustalovat, v hrobech přibývá výbavy, která souvisela především s katolickou vírou. Postupně přichází doba, kdy je mysl lidí stále více ovládána barokní zbožností, provázena symbolikou, jež měla napomáhat lepšímu chápání a snášení smrti (obr. 1). V pohřebním ritu 


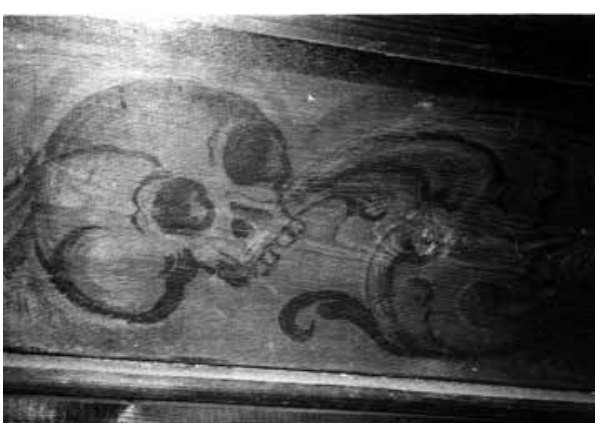

Obr. 1. Kapucínský kostel v Brně, krypta. Téma smrti, malovaná výzdoba na dřevěné rakvi. Foto M. Králíková. Abb. 1. Kapuzinerkirche in Brno, Krypta. Thema Tod, gemalte Verzierung auf einem Holzsarg. Foto M. Králíková. se projevuje nadměrná okázalost, nákladnost a snaha o zdůrazňování sociálního postavení, př́edevším u pohřbů šlechty a městské honorace.

\section{Katolický pohřební ritus - hřbitovy}

At' už bohatí či chudí, katolíci projevovali většinou snahu, aby jejich pohřeb nebo pohřeb př́ibuzných splňoval nezbytné náležitosti katolického pohřbu - aby se jim dostalo posledního pomazání, rozhřešení, aby jejich tělo na poslední cestu vyprovodil kněz (např. Králíková 2007, 23-36; Mikulec 2007, 163186; Orlita 2007, 187-208) a především, aby po smrti jejich tělo spočinulo na posvěceném místě. Takovým místem vhodným $\mathrm{k}$ pohřbu byl především katolický hřbitov. Lepší variantou byl hřbitov rozkládající se okolo kostela, popř. $\mathrm{v}$ jeho bezprostřední blízkosti. Tam bývali pohřbíváni, zvláště ve městech, zámožnější jedinci a jejich rodiny. Méně výhodnou a podřadnější možností byly hřbitovy za hranicemi obcí, které zde vznikaly dle nařízení z hygienických a prostorových důvodů, kdy hřbitovy kolem městských chrámů byly již přeplněny. Tato nařízení vycházela z dekretů císaře Josefa II. z roku 1784 (Kunc 1937, 51) a předepisovala i to, jak má nový hřbitov vypadat a jak má být užíván. Nově vznikající hřbitovy již nutně nemívaly ve svém areálu kostel. Sloužily totiž pro osoby z nižších sociálních vrstev (řemeslníky, obchodníky, zemědělce), pro občany z okolních vsí, cizince, městskou chudinu apod. Kromě toho vznikaly i hřbitovy speciální, např. chudinské, vojenské, špitální a klášterní, zde také pravděpodobně skončila těla nemanželských dětí a opovrhovaných osob. Posledně zmínění (patří sem např. delikventi, sebevrazi, kati, rasové, podezřelí z čarodějnictví apod.) bývali také pohřbíváni na místě nejméně váženém - u samé hřbitovní zdi, popř. zcela mimo posvěcenou půdu, tedy za zdí hřbitova.

Prostor hřbitova býval řádně vymezen a opatřen vstupní branou. Tato mechanická bariéra - prŕírodní ohrazení, dřevěná, častěji však již kamenná zed’ - byla nejen ochranou proti volně se pohybujícímu zvířectvu, ale tvořila i symbolické vymezení světa mrtvých od světa živých. Také plocha hřbitova byla s největší pravděpodobností více či méně rozčleněna. Jedním z důvodů byla opět sociální diferenciace, kdy si zámožnější a výše postavení zajištovali místa co nejblíže kostelu (nejlépe presbytáři, tzn. co nejblíže svatým). Čím bylo místo dále od kostela, tím bylo považováno za podřadnější. Slábnoucí intenzita pohřbů spolu se zvětšující se vzdáleností od kostela byla zachycena při některých archeologických výzkumech, např. v Brně u kostela sv. Jakuba (Zůbek 2013, 52). Na hřbitovech bez kostela za nejlepší platila pohřební místa poblíž centrálního kř́iže a podél hlavní cesty, která $\mathrm{k}$ němu vedla.

Pro novověké hřbitovy bylo charakteristické uspořádání hrobů do víceméně pravidelných řad. Na povrchu byly hroby označovány dřevěnými, později stále častěji kamennými křiži a náhrobky. Přesto docházelo ke vzájemnému porušování hrobů, a to hrobů starších, uložených ve větších hloubkách. Týká se to především etážových pohřbů na hřbitovech, které svému účelu sloužily již od středověku. Příklad takového pohřbívání najdeme na Hodonínsku u kostela sv. Kunhuty v Čejkovicích, kde byly zachyceny dvě až tři úrovně pohřbů (Kostrouch 2011, 140), nebo na Šumpersku na hřbitově u kostela sv. Tomáše v Mohelnici, kde se místy prokázalo dvě až sedm pohřebních vrstev (Zeman 2015, 285). Především u hřbitovů s několika pohřebními horizonty lze vlivem opakovaného pohřbívání také častěji sledovat nárůst terénu vůči okolí.

Při narušení staršího hrobu se někdy praktikovalo druhotné uložení kosterních ostatků $\mathrm{z}$ tohoto hrobu do hrobu mladšího. Kosti se daly na hromádku do rohu nového hrobu nebo podél jeho stěny. Dalším druhotným způsobem uložení kosterních ostatků je jejich umístění do 

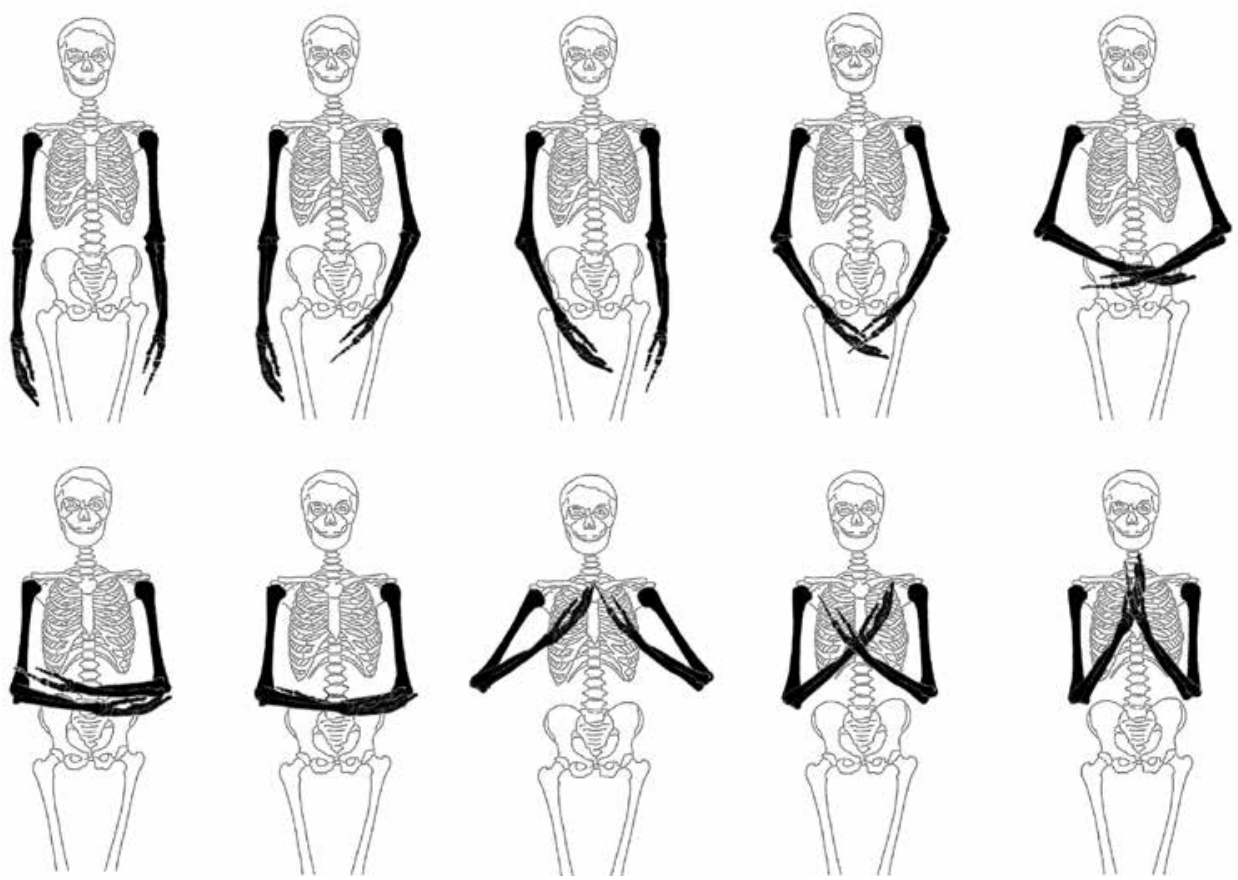

Obr. 2. Polohy paží pohřbených jedinců v novověkých hrobech. Kresba M. Králíková.

Abb. 2. Lage der Arme von bestatteten Individuen in neuzeitlichen Gräbern. Zeichnung M. Králíková.

velkých společných jam na hřbitově nebo při kostelní zdi. Např́iklad Dlouhá Lhota u Blanska (Berkovec 2002, 254), Krhov na Třebíčsku (Obšusta 1999, 426) nebo Boršice u Buchlovic na Uherskohradišt'sku (Snášil 1973, 62).

Dřive tradiční zeměpisná orientace hrobů hlavou k západu (srov. Dąbrowska 1997, 8) nebyla v novověku striktně dodržována. Při pohřbívání se lidé řídili orientací samotných kostelů, ty však právě v novověku již nevykazovaly pravidelnou západovýchodní orientaci. Při archeologických výzkumech hřbitovů bývají zaznamenávány orientace ve všech možných zeměpisných směrech (i v rámci jednoho pohřebiště). Vzhledem k přeplněnému stavu některých (zvláště městských) hřbitovů je možné, že orientace se mimo jiné řídila také volným místem na hřbitově a že právě některé odlišné orientace hrobů mohly znamenat úsporu místa.

Od 16. století je zaznamenána změna zeměpisné orientace kněžských pohřbů. Dříve západovýchodní orientace se změnila na východozápadní (tedy hlavou k východu), tj. pohledem směrem $\mathrm{k}$ věřícím (srov. Unger 2002, 45). K identifikaci hrobu duchovního může napomoci nejen specifický oděv, v němž byl jedinec pohřben, ale také př́itomnost doprovodného nálezu v podobě kalichu jakožto symbolu kněžské insignie. Kalich se přidával do hrobu kněžím již od středověku, nalézt ho lze však i v hrobech novověkých. Zbytky po dřevěném kalichu byly nalezeny např́íklad v rakvi kněze (dle nápisu Henrica Ernesta Alexandra Halamy) pohřbeného v roce 1761 v kryptě pod presbytářem brněnského kostela sv. Petra a Pavla (Schram 1896, 25). Z téhož kostela pochází hroby kněží pohřbených v lodi kostela s kalichem přikrytým nádobou dnem vzhůru. Podle keramických nádob byly hroby datovány do přelomu 15. a 16. století, některé mohly pocházet až z druhé poloviny 16. století (Unger 1997, 646-647). Jejich orientace hlavou k západu však odpovídá ještě starým zvykům.

Obvyklá je u novověkých pohřbů poloha na zádech s nataženými dolními končetinami. Pokud se najdou nějaké odchylky od této polohy, jedná se o nestandardní pohřby a nerituální 


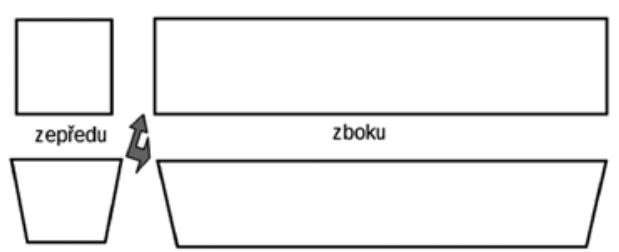

Obr. 3. Tvarové typy rakví - tvar rovnoběžníku a lichoběžníku. Kresba M. Králíková.

Abb. 3. Sargformtypen - Rechteck- und Trapezform. Zeichnung M. Králíková.

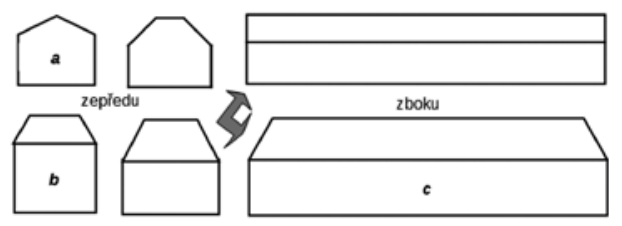

Obr. 4. Tvarové typy rakví. a - střechovité víko, b-lomené víko, rozdělená čelní a nožní deska, c - zkosené víko rakve. Kresba M. Králíková.

Abb. 4. Sargformtypen. a - dachförmiger Deckel, b - gebrochener Deckel, geteilte Kopf- und Fußplatte, c - abgeschrägter Sargdeckel. Zeichnung M. Králíková.

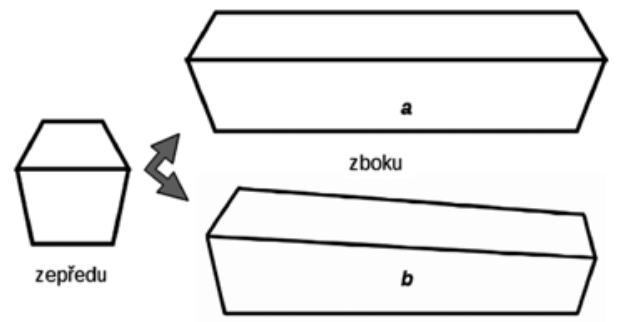

Obr. 5. Tvarové typy rakví - zkosené víko i tělo rakve. Kresba M. Králíková.

Abb. 5. Sargformtypen - abgeschrägter Deckel und Sargkörper. Zeichnung M. Králíková. jsou v minimálním počtu. Stejně tak nepř́ítomnost hřebíků nemusí znamenat pohřeb bez rakve, nebot' rakve mohly být vyrobeny za pomoci jiné spojovací techniky, např. pomocí čepů nebo šindelovou technikou. Obecně je platné, že od 17. století počet pohřbů v rakvi narůstal.

Nejlépe zachované rakve, včetně malby a barokní výzdoby, najdeme v kostelních kryptách. Podle nich můžeme sledovat určitý vývoj tvaru, techniky výroby, výzdobu a další. Zjednodušeně uvádím několik základních typů, v praxi je možno setkat se s různými dalšími tvarovými odchylkami. Nejjednodušší a nejstarší byly rakve truhlového nebo vanového typu, které měly na průřezu tvar téměř pravidelného rovnoběžníku, později se tvar měnil na lichoběžníkovitý (obr. 3). Dále se může vyskytovat rakev truhlová se střechovitou horní částí (obr. 4a), kdy čelní a nožní desky jsou zpravidla kolmé a jednodílné, nebo s víkem již lomeným. Následně dochází k rozdělení čelních a nožních desek na dva díly (obr. 4b), přičemž poměr obou výšek mohl být rozmanitý. U novějšího typu došlo ke zkosení víka (obr. 4c) anebo ke zkosení víka i těla 


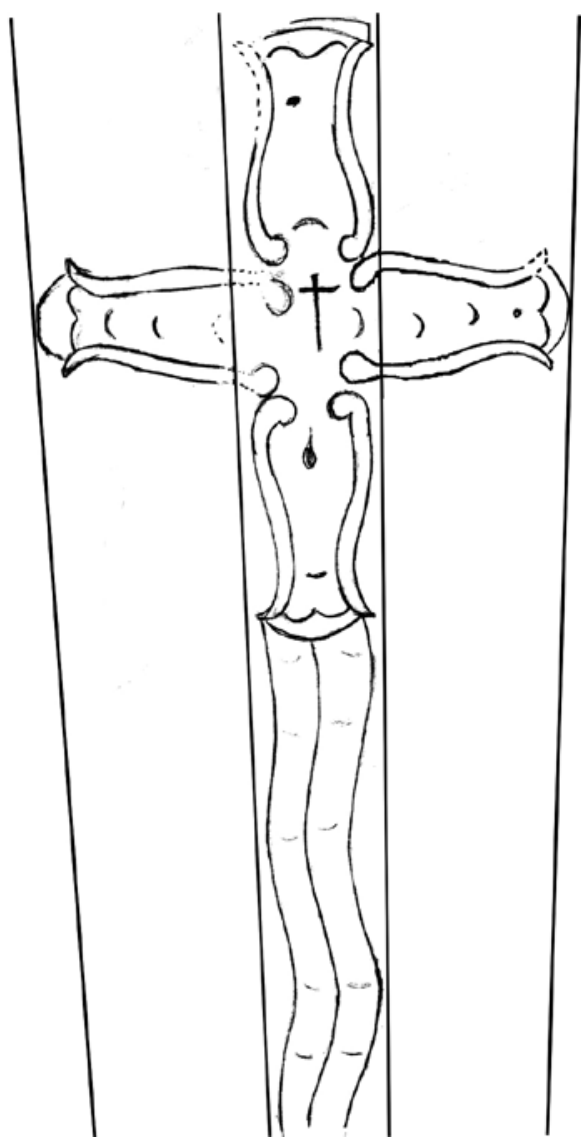

Obr. 6. Křižanovice u Vyškova, kostelní krypta. Malba na víku rakve. Doplnila M. Králíková.

Abb. 6. Křižanovice bei Vyškov, Kirchenkrypta. Bemalung auf einem Sargdeckel. Ergänzt von M. Králíková.

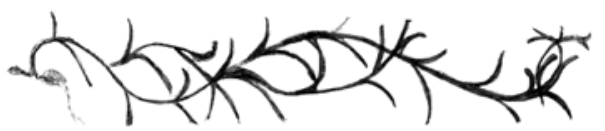

Obr. 7. Křrižanovice u Vyškova, kostelní krypta. Malba na bočnici rakve. DopInila M. Králíková.

Abb. 7. Křižanovice bei Vyškov, Kirchenkrypta. Bemalung auf einer Sargseitenwand. Ergänzt von M. Králíková. rakve (obr. 5), což znamená, že jsou zkoseny obě části čelní i nožní desky. Nakonec došlo k vyvýšení hlavové části rakve (obr. 5b). Při dataci rakve podle typu je ovšem potřeba si dávat pozor na skutečnost, že i v mladším období se mohly používat starší typy rakví. Jako výzdoba se uplatňovala nejčastěji obrysová malba černou barvou. Bývá více či méně umělecká, někdy spíše primitivní, zřejmě byl často autorem nějaký lidový tvůrce. Opakujícím se výzdobným motivem byl latinský kříž, popř. lebka se zkř́žženými hnáty (obr. 8), nápis IHS a jiná ornamentální výzdoba. Někdy nesou rakve identifikační štítky s popisem. Příslušníci šlechty a významné osoby mají dřevěnou rakev vloženou ještě do kovové schránky z cínu, zinku, olova apod.

\section{Pohřby v sakrálních stavbách}

Mezi populárnější a nákladnější pohřby patřily ty uskutečněné $\mathrm{v}$ kostelech a klášterech. Takové pohřby byly zpočátku vyhrazeny osobám duchovním (biskupové, opati, kněží, řádoví př́slušníci) a také osobám společensky významným (majitelé a patroni kostelů, jejich fundátoři, rektoři, vojevůdci, architekti, lékaři, vysocí úředníci apod.). Od 17. století se pohřby v kostelech staly populární natolik, že si pohřeb vymáhali a předpláceli i občané z řad nejen šlechty, ale i zámožných měšt’anů. Šlo především o demonstraci majetkové a sociální úspěšnosti.

Pohřbívalo se do hrobů pod dlažbou, někdy se užívaly větší sklípky či komory vyzděné cihlami. Stejně jako na hřbitově i v kostele vládla hierarchie pohřebních míst. Být pohřben co nejblíže svatým a zajistit si tak jejich přímluvu bylo nejvíce žádoucí, a tak mezi nejhodnotnější místa patřila ta nejblíže kněžiště a oltáře, anebo alespoň v ose kostela. Oblíbené bylo pohřbívat také $\mathrm{v}$ kostelních kaplích, kde vznikaly rodinné hrobky. V klášterech se pohřbívalo $\mathrm{v}$ ambitech a rajských dvorech. Hroby byly překrývány náhrobními deskami,

které později končily jako náhrobníky na zdech kostelů a hřbitovů.

Téměř v každém okrese na Moravě najdeme kostel, v němž se v novověku pohřbívalo. Vyjma již zmíněných brněnských kostelů (sv. Jakuba, sv. Petra a Pavla, sv. Tomáše; Procházka-Zatloukal 1991 ad.) je to např. kostel sv. Václava v Břeclavi (Králíková 2007, 167-179), minoritský klášter a kostel Nanebevzetí P. Marie v Jihlavě (Hejkal-Hrubý-Mráz 2004, 101), kostel sv. Marka a kostel sv. Filipa a Jakuba v Litovli (Faltýnek 2000; 2000a, 76), dóm sv. Václava v Olomouci 


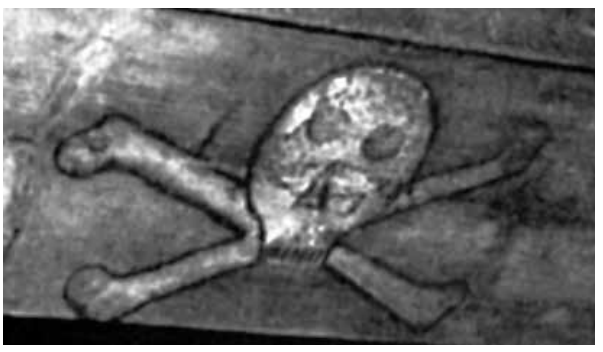

Obr. 8. Pohořelice, kostel sv. Jakuba Většího. Symbol smrti - lebka a zkřížené hnáty - na rakvi. Podle Unger 2000, obr. 14, upravila M. Králíková.

Abb. 8. Pohořelice, Kirche des St. Jakobus. Todessymbol Totenkopf mit gekreuzten Knochen - auf einem Sarg. Nach Unger 2000, Abb. 14, geändert nach M. Králíková.
(Burian 1972, 126; 1992, 330), kostel sv. Václava v Ostravě (Zezula 1999, 357) a další (viz obr. 12).

Stejně tak v mnoha moravských kostelech a v některých klášterech byly vybudovány podzemní krypty. Bývaly př́stupné z interiéru kostela, kde bývá vstup zakryt náhrobním kamenem, a někdy jsou př́stupné i z exteriéru. Původně sloužily zřejmě k uctívání relikvií mučedníků (Fingerlin 1992, 207), od přelomu 15. a 16. století $\mathrm{k}$ pohřbům nebo jako ossaria k druhotnému uložení kosterních ostatků z rozrušených hrobů. Do krypt byly pohřbívány zpočátku osoby stavu duchovního (hlavně řádoví příslušníci), ale brzy je začaly využívat také osoby světské, především šlechta, bohatí měštané a jiné významné osoby. Větší po-

hřební prostory se budovaly jednak pro úsporu místa (vešlo se tam více jedinců než do jednotlivých hrobů) a jednak z důvodu sloučení pohřbů příslušníků jedné rodiny či rodu do společného prostoru. Kryptu často tvořilo více komor spojených chodbami. Těla zde byla ukládána bud' v rakvích, nebo na holou zem (obr. 9). V těchto případech se jedná o pohřby řádových př́slušníků v řádovém rouchu a jen s nezbytnými atributy (kř́ž, růženec), kteří tímto uniformním způ-

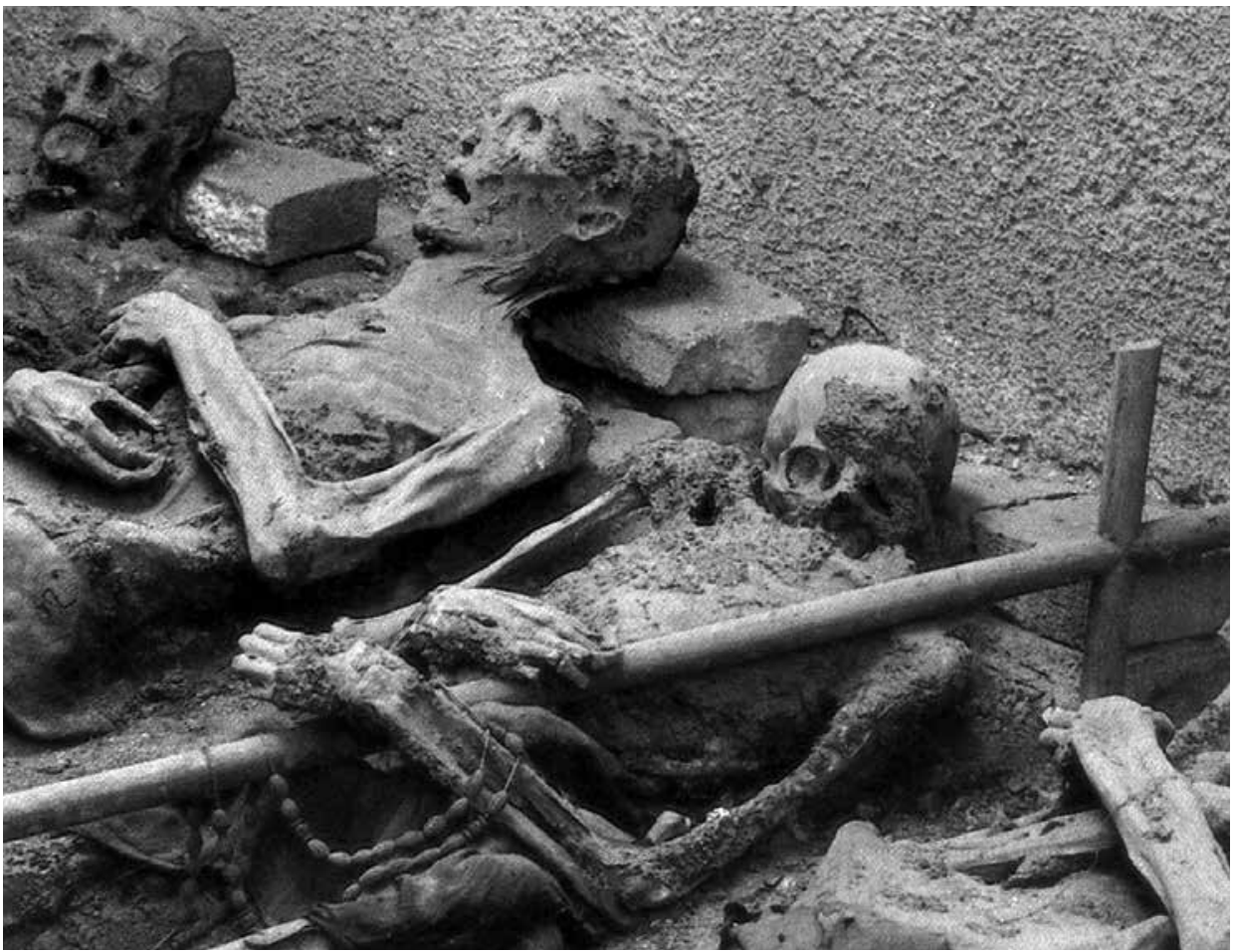

Obr. 9. Kostel Nalezení sv. Kříže v Brně, krypta. Pohřbení kapucínští mniši. Foto M. Králíková.

Abb. 9. Kirche der Auffindung des heiligen Kreuzes in Brno, Krypta. Bestattete Kapuzinermönche. Foto M. Králíková. 


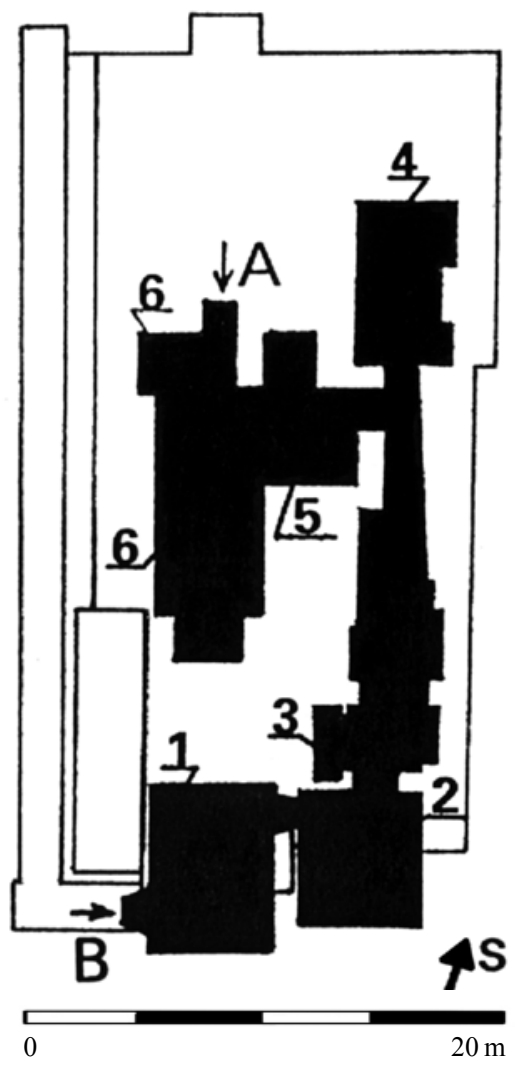

Obr. 10. Kostel Nalezení sv. Kř́iže v Brně. Půdorys krypty. Kresba M. Králíková.

Abb. 10. Kirche der Auffindung des heiligen Kreuzes in Brno. Grundriss der Krypta. Zeichnung M. Králíková. sobem pohřbu vyjadřovali svoji skromnost a chudobu. Př́íkladem jsou kapucínští mniši pohřbení pod kostelem Nalezení sv. Kř́iže v Brně (Králíková 2007, 92). Krypta je velmi rozsáhlá (obr. 10) a zaujímá velkou část půdorysu samotného kostela. Kromě mnichů zde spočinulo na 205 laiků, dobrodinců kláštera a významných Brňanů. V Brně se krypty nachází ještě pod kostelem sv. Petra a Pavla (krypta kanovníků; Králíková 2012, 276), pod jezuitským kostelem Panny Marie, kde kromě mnichů dodnes v rakvi odpočívá rektor koleje páter Martin Středa (obr. 11), pod kostelem sv. Tomáše, kde byli v 18. století pohřbíváni augustiniáni, pod kostelem sv. Michala, kde bývali pohřbíváni př́islušníci dominikánského řádu (Králíková 2007, 91-93). V kryptě pod kostelem sv. Jakuba bylo objeveno 24 malovaných dřevěných rakví obsahujících rozrušené kosterní ostatky, zbytky textilních a kožených oděvů a devocionálie (Černá et al. 2012, 116; Zůbek 2013, 17). V kryptě kostela byl pohřben také maršál Raduit de Souches († 1682), známý obránce města Brna proti Švédům. Jeho ostatky byly uloženy $\mathrm{v}$ dřevěné rakvi, která byla vložena ještě do rakve měděné. $Z$ jeho pohřbu zůstaly dochovány textilní zbytky oděvů, kožená obuv a části z růžence (Novotný 1967, 56-57). Mezi další moravské lokality (obr. 12) patří Vyškov, kde byli v kostele při městském hřbitově pohřbíváni kapucínští řádoví bratři (Zemanová-Petrů 1973, 10), kapucíni také v kryptě klášterního kostela sv. Jana

Kr̆titele ve Znojmě (David-Soukup 2002, 296), tamtéž krypty v minoritském klášteře (UngerKos 2002, 306), Olomouc - krypta františkánů v kostele Neposkvrněného početí P. Marie (M1čák 1984, 344), Uherské Hradiště - př́íslušníci františkánského kláštera v kostele Zvěstování P. Marie (Kohoutek 1999, 147), Opava - dominikánský klášter a kostel sv. Václava (Šikulová 1970, 67) a další.

Je potřeba také zmínit rodové krypty zakládané příslušníky šlechty, kteří svými pohřby demonstrovali své sociální postavení a majetnost. Známými př́íklady jsou krypta Liechtensteinů v kostele Narození P. Marie ve Vranově u Brna (Král 1969, 121; 1984, 69), krypta Žerotínů v Židlochovicích (Král 1969a, 61; 1981, 329), Dietrichsteinové v kostele sv. Anny v Mikulově (Klanicová-Peška 1993, 80; Drozdová 2006) nebo krypta v kostele Nalezení sv. Kříže v Doubravníku (David-Soukup 2002, 53), která sloužila od 16. století k pohřbům Pernštejnů. Po vzoru šlechty se nechávali v kryptách pohřbívat také zámožní měštané a jiné významné světské osoby. Jejich pohřby nalezneme v kryptách v Olomouci v kostele Neposkvrněného početí P. Marie (Mlčák 1984, 344), v Prostějově v augustiniánském klášteře (Čižmář-Šmíd 1999, 363-364), v Litovli v kapli sv. Jiří (Kauerová-Koudela 1998, 70-71), v Jihlavě v kostele Povýšení sv. Kříže (Zatloukal 1999, 417) nebo v kostele sv. Jakuba Většího (Zimola 2004, 200-201), v Uherském Hradišti v kostele sv. Fr. Xaverského (Kohoutek 1999, 147-150) a jinde (obr. 12). Pohřbívání v kostelech bylo zakázáno Josefem II. $v$ roce 1783 z důvodu přeplněnosti, a tedy možnosti snadného šíření epidemických chorob. 


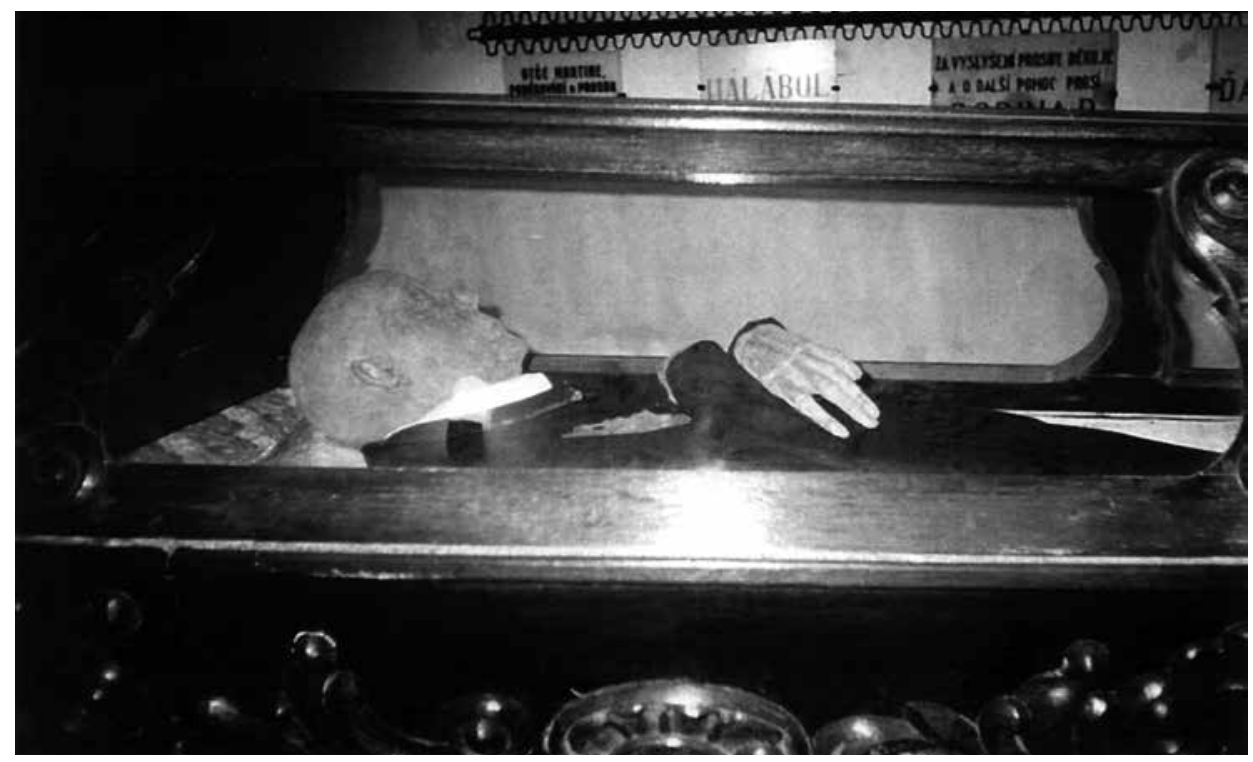

Obr. 11. Kostel Panny Marie v Brně. Rektor jezuitské koleje P. Martin Středa († 1649). Foto M. Králíková. Abb. 11. Jungfraumarienkirche in Brno. Rektor des Jesuitenkollegs P. Martin Středa († 1649). Foto M. Králíková.

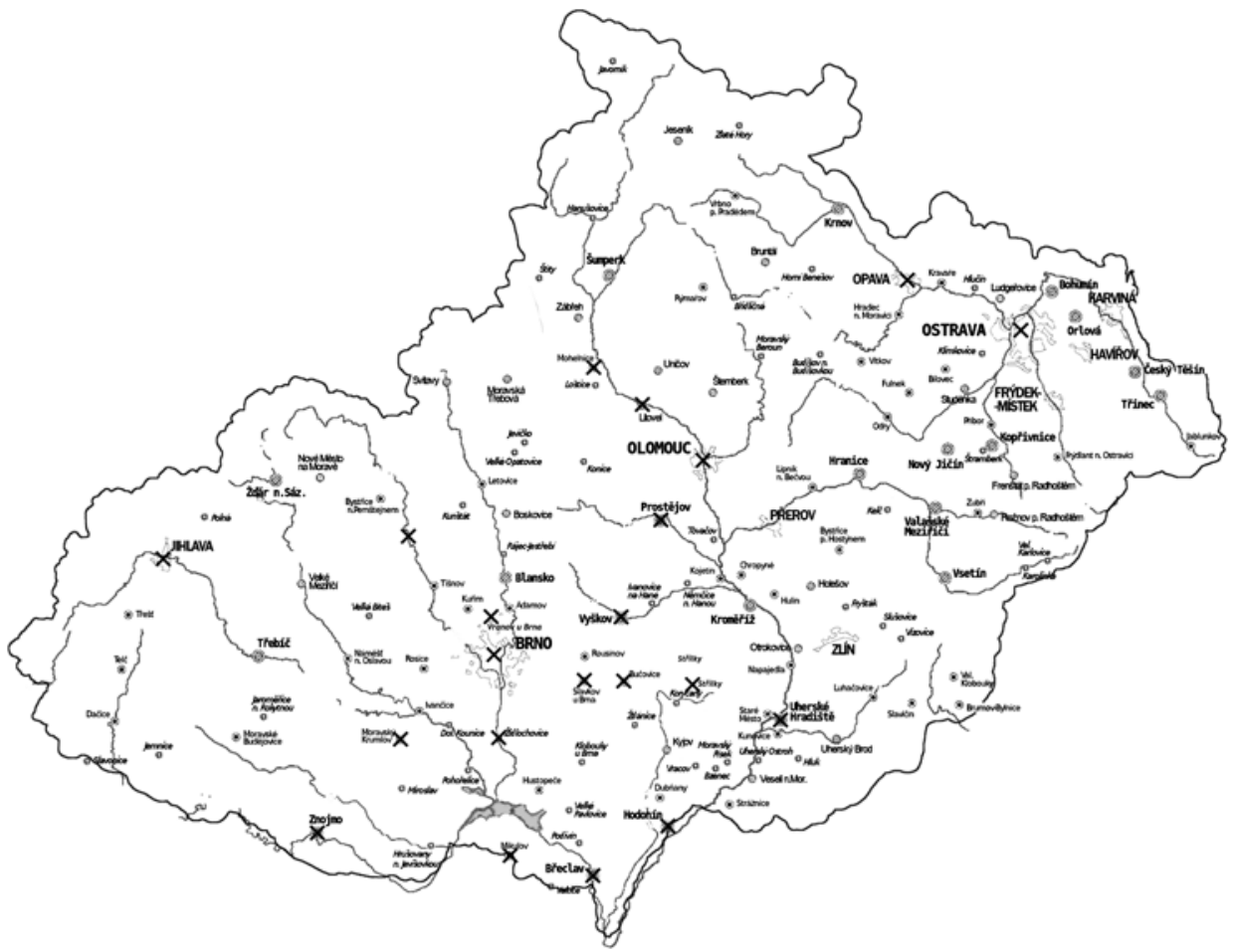

Obr. 12. Mapa Moravy s vyznačením některých lokalit s novověkými pohřby. Upravil M. Králík.

Abb. 12. Karte von Mähren mit Kennzeichnung einiger Fundstellen mit neuzeitlichen Bestattungen. Geändert nach M. Králík. 

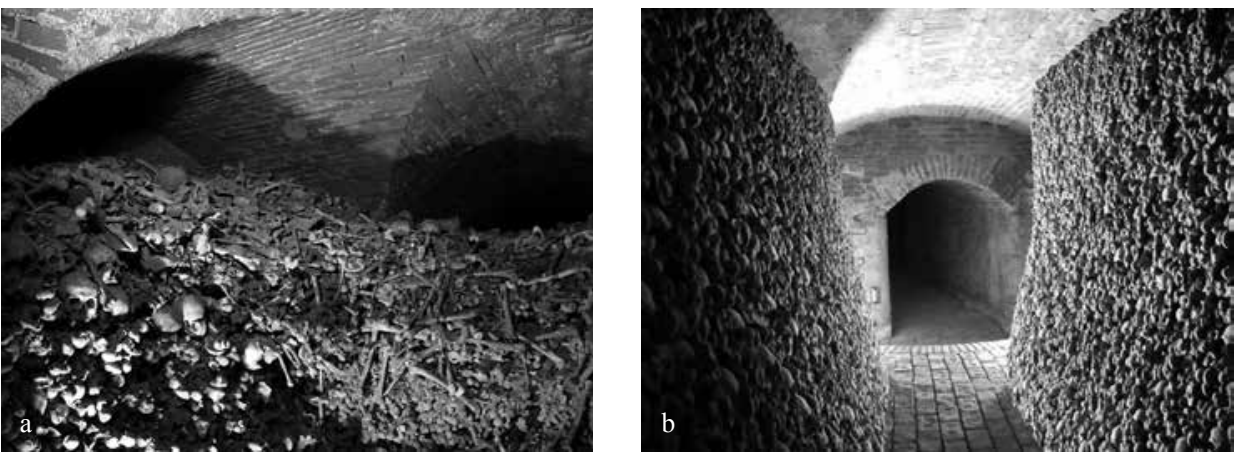

Obr. 13 a, b. Kostel sv. Jakuba v Brně, ossarium. Zdroj http://www.tisnovka.cz/prehled-praci/?author\%5B0\%5D=3\&type $\% 5 B 0 \% 5 D=4 ;$ http://www.leosdrahota.cz/gkostnice.html.

Abb. 13 a, b. St. Jakobskirche in Brno, Ossarium. Quelle http://www.tisnovka.cz/prehled-praci/?author\%5B0\%5D=3\&typ e\%5B0\%5D=4; http://www.leosdrahota.cz/gkostnice.html.

Od 16. století začaly vznikat rodinné hrobky v podobě kaplí na hřbitovech i na soukromých pozemcích. Jejich počet se ale hlavně rozšířil v 18. století, zřejmě v souvislosti s postupně se měnícím náhledem na smrt, který se začal uplatňovat přibližně od poloviny 18 . století, kdy se veřejný projev smrti pozvolna proměňoval na prožívání smrti v soukromí. Hrobky si nechala budovat šlechta a významní a zámožní měšt’ané. Př́íkladem měštanské kaple s hrobkou byla stavba u bučovického kostela, kterou nechal vystavět pro sebe a svou rodinu purkmistr Michal Žarošský roku 1693. V roce 1826 byla tahle kaple zbořena a o několik metrů dále vystavěna nová (obr. 18; Tihelka 1950, 65). Ta neobsahuje hrobku a vzpomínkou na původní kapli je již jen pamětní deska na ní umístěná. Ve Slavkově u Brna se nachází kaple u bývalého špitálního kostela, nachází se v ní hrobka (obr. 19) významného moravského rodu Kouniců. Nechal ji vystavět Arnošt Kaunitz-Rietberg v roce 1794 (Prahl et al. 2004, 279). Další hrobka významného moravského rodu se nachází v Moravském Krumlově. Patří Liechtensteinům a nechala ji v roce 1789 zbudovat pro sebe a svého manžela Marie Eleonora z rodu Oettingen-Spielberg (Kroupa 1986, 108-109). Na hřbitově ve Stř́lkách byla ve 30. letech 18. století vybudována kaple Petřvaldských (obr. 20), tehdejších místních majitelů panství. V hrobce jsou pohřbeni Künburgové (Krsek et al. 1996, 309).

\section{Ossaria - druhotná úložiště}

Podzemní prostory pod kostely, popř. kaplemi byly využívány k druhotnému ukládání kosterních ostatků ze starých zrušených hrobů na hřbitovech kolem kostelů, kde musely uvolnit místo pro nové pohřby, nebo za okolností rušení celých hřbitovů. Jedna z největších kostnic Evropy, co do množství uložených ostatků, se nachází právě na Moravě. Jde o kostnici v podzemí kostela sv. Jakuba v Brně (obr. 13a, b). Tvoří ji asi $25 \mathrm{~m}$ dlouhá chodba pod kostelní lodí, která spojuje tři boční komory, spojené navzájem průchody. Do stř̌ední části krypty ústí vstup z interiéru kostela. Prostory byly zbudovány současně asi ve druhé polovině 17 . století, ale zaplněny ostatky byly zřejmě později (Černá et al. 2012, 116). Pod kostelem Panny Marie ve Křtinách jsou uloženy ostatky téměř tisíce občanů (obr. 14), kteří byli původně pohřbeni na hřbitově u kostela. Z krypty pochází soubor dvanácti lebek označených kresbou ve tvaru vavř́nového věnce a písmene T na čele (obr. 15; Šenkyř́ík 1992, 28-29). Kresby pochází dle odborníků ze 17. století. Snaha o identifikaci těchto lebek byla bohužel neúspěšná, spekuluje se ovšem, že pravděpodobně patřily nějaké skupině významných osob. Jako ossarium sloužila také krypta pod kostelem sv. Mikuláše ve Znojmě. Ve dvou komorách zde byly uloženy ostatky asi z 200 jedinců (Čižmář 2004, 249-250; Cimbůrková 2007, 183). 


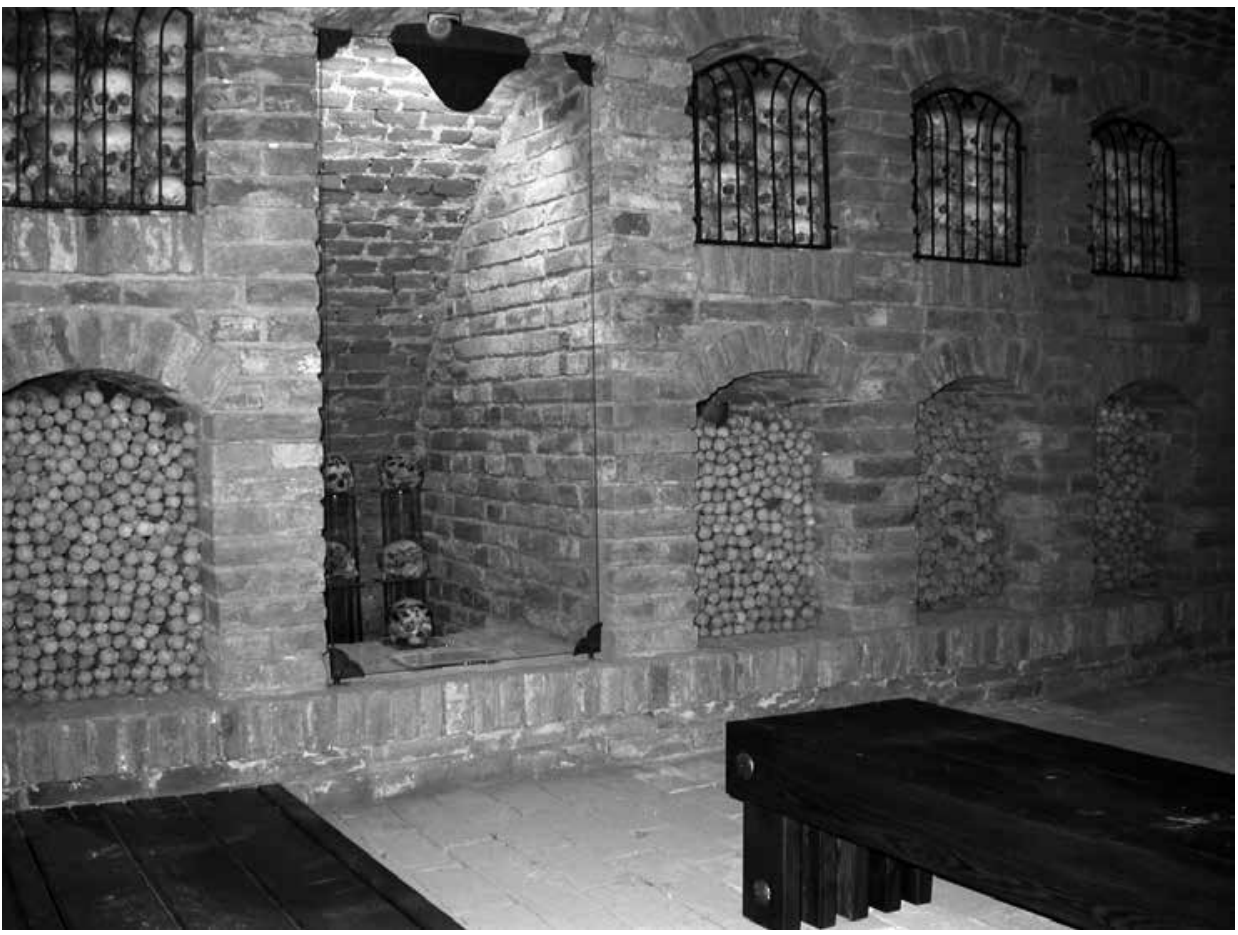

Obr. 14. Křtiny, kostel Panny Marie, ossarium pod kostelem. Foto M. Králík.

Abb. 14. Křtiny, Jungfraumarienkirche, Ossarium unter der Kirche. Foto M. Králík.

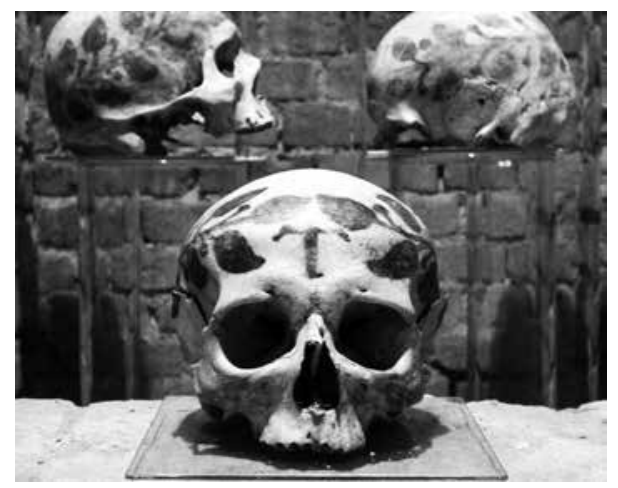

Obr. 15. Křtiny, kostel Panny Marie, krypta. Malované lebky. Foto M. Králík.

Abb. 15. Jungfraumarienkirche, Krypta. Bemalte Schädel. Foto M. Králík. vyskládány do čtyř hranic o rozměrech $2 \times 2 \times 2,5 \mathrm{~m}$ (obr. 16; Prchal 2002, 34). Losenická kostnice (obr. 17) stojí u kostela sv. Jakuba Většího. Postavena byla v roce 1746 na popud knížete Karla Maxmiliána z Dietrichsteinu (Vítejte na Vysočině 2016).

Kosterní ostatky ze zrušených hrobů bývaly ukládány také do staveb $\mathrm{k}$ tomu speciálně určených - kostnic. Jedná se většinou o jednopodlažní a jednoprostorové stavby. Uvnitř bývá oltář a nachází se tam dnes již umně seskládané lidské kosti, někde jsou uskladněny i pod podlahou. Kostnice mohly v minulosti fungovat i jako márnice. V okrese Žd'ár nad Sázavou se nachází hned dvě takové stavby. Jedna je v Nížkově a druhá ve Velkých Losenicích. Nížkovská kostnice je čtyřboká stavba $\mathrm{z}$ roku 1709. Přiléhá $\mathrm{k}$ barokní bráně bývalého hřbitova kolem kostela sv. Mikuláše. Nechal ji vybudovat děkan Heberlandt. Její půdorys je $6 \times 6$ metrů a zdi jsou dvojité. Mezi stěnami se udržuje stálá vlhkost vzduchu, čímž je vlastně celý interiér jakoby zakonzervován. Kosti asi sedmi tisíc zemřelých saských, francouzských, bavorských a pruských vojáků jsou zde 


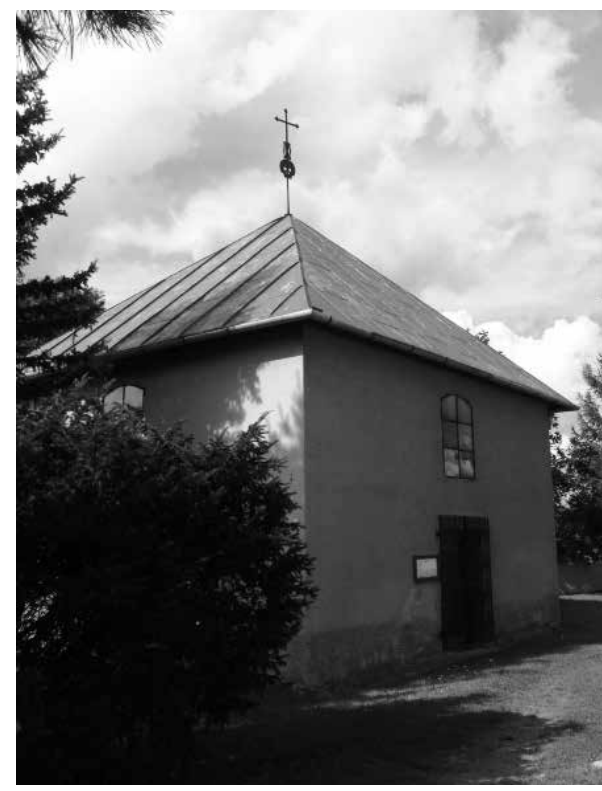

Obr. 16. Nížkov, kostnice. Zdroj http://www.region-vysocina.cz/kostnice-cx1114.

Abb. 16. Nížkov, Beinhaus. Quelle http://www.region-vysocina.cz/kostnice-cx1114.

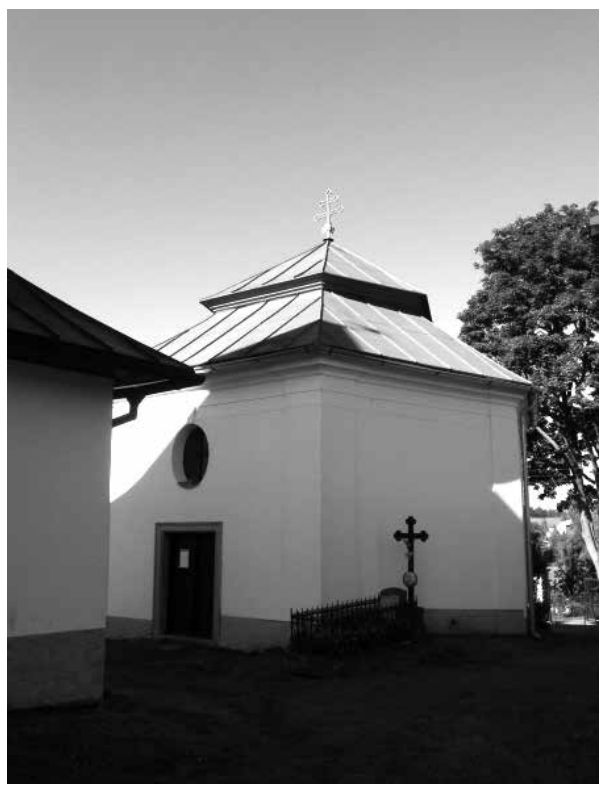

Obr. 17. Velká Losenice, kostnice. Zdroj http://www.region-vysocina.cz/kostnice-velka-losenice-cx 29.

Abb. 17. Velká Losenice, Beinhaus. Quelle http://www.region-vysocina.cz/kostnice-velka-losenice-cx 29.

\section{Specifika v pohřbívání - vícenásobné a hromadné hroby}

Vícenásobné pohřby dvou až osmi osob, ve kterých najdeme společně děti s dospělými, můžeme považovat za hroby rodinné. Takové se nachází v rámci pohřebních areálů. Rodinný pohřeb byl nalezen například v Mohelnici na Šumpersku na hřbitově u kostela sv. Tomáše (Zeman 2015, 285-6) nebo v Brně na hřbitově u Sv. Jakuba (Zůbek 2013, 88).

Pohřby do hromadných hrobů řadím mezi pohřby vzniklé za mimořádných situací či okolností. Těmi mohou být nejčastěji epidemie, větší množství civilistů zemřelých při vojenské akci anebo pohřby chudých obyvatel. Takové hroby se mohou nacházet na hřbitovech, ale z důvodu nedostatku místa či z hygienických důvodů se mohou nacházet i mimo hřbitovní prostory. Hroby obětí epidemie lze identifikovat podle vápna, kterým se hroby zasypávaly kvůli dezinfekci. Hrob s několika jedinci zasypaný vápnem a smůlou byl objeven např́klad v Mařaticích na Uherskohradišt’sku (Pavelčík 1996). V Ostravě byly v místě někdejší farské zahrady, tedy za hranicí hřbitova u Sv. Václava, pohřbeni jedinci zemřelí zř̌ejmě při nějaké epidemii, a to pietním způsobem, na zádech, s pažemi podél těla a hlavou víceméně k západu. Hrob čítal asi deset jedinců a pocházel ze druhé poloviny 16. století (Moravec a kol. 2014, 18). Hromadné hroby s větším počtem jedinců, které byly naopak součástí hřbitova, se nacházely u brněnského kostela sv. Jakuba (Zůbek 2013, 90, 91).

V rámci civilních hřbitovů můžeme najít také hroby padlých vojáků, někdy však pro ně byly budovány speciální hřbitovy. Vojenské hroby obsahují často větší množství pohřbených osob a jejich skelety obvykle vykazují stopy zranění nebo amputací končetin. V areálu Výstaviště Flora v Olomouci byl zachycen vojenský hřbitov, jenž byl zřejmě okrajovou součástí odkrytého katolického hřbitova, založeného v 80. letech 18. století a fungujícího po celé 19. století. Hroby obsahovaly deset až čtyřicet jedinců především mužského pohlaví, bez milodarů a osobní výbavy. Mladší civilní hroby na části hřbitova porušovaly většinu hromadných hrobů vykazujících 


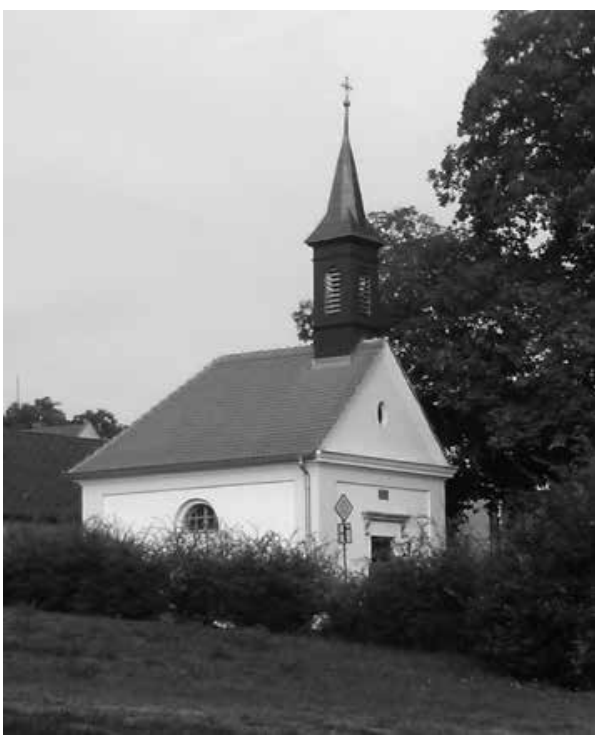

Obr. 18. Bučovice, pohřební kaple Žarošských. Foto M. Králíková.

Abb. 18. Bučovice, Begräbniskapelle der Familie Žarošský. Foto M. Králíková.

prvky vojenských pohřbů. Starší vojenský hřbitov tak byl následně využit pro mladší civilní pohřby (Hadrava a kol. 2014, 243; Kováčik-Hadrava 2015, 296). Celkem šest hromadných hrobů po sedmi zemřelých bylo odkryto v Želešicích u Brna. Jeden z předpokladů je, že se jedná o pohřby vojáků padlých v souvislosti s obléháním města Brna Švédy roku 1645 (Kos 2004, 251).

Do společných hrobů bývaly pohřbívány osoby vyčleněné na okraj společnosti, a to většinou mimo katolické hřbitovy. Můžou sem tedy patřit různí heretici, kteří nesměli spočinout mezi katolíky, dále delikventi, sebevrazi, podezřelí z čarodějnictví či vampyrismu. Pro takové hroby je typické nerituální uložení těl (na boku, na břiše, mívají v hrobě kameny, zámky či jiné atypické předměty). V Mohelnici na Šumpersku bylo v hrobě uloženo šest jedinců v neanatomických polohách (na boku nebo na břiše) a s orientací opačnou vzhledem k běžným pohřbům (Zeman 2015, 285).

\section{Hrobový inventár̆}

Součástí pohřbu (ve smyslu pohřebního úkonu) se stávají předměty s ním bezprostředně související, jako součásti rakve (hřebíky, plastická výzdoba, rukojeti, kování, výstelka apod.),

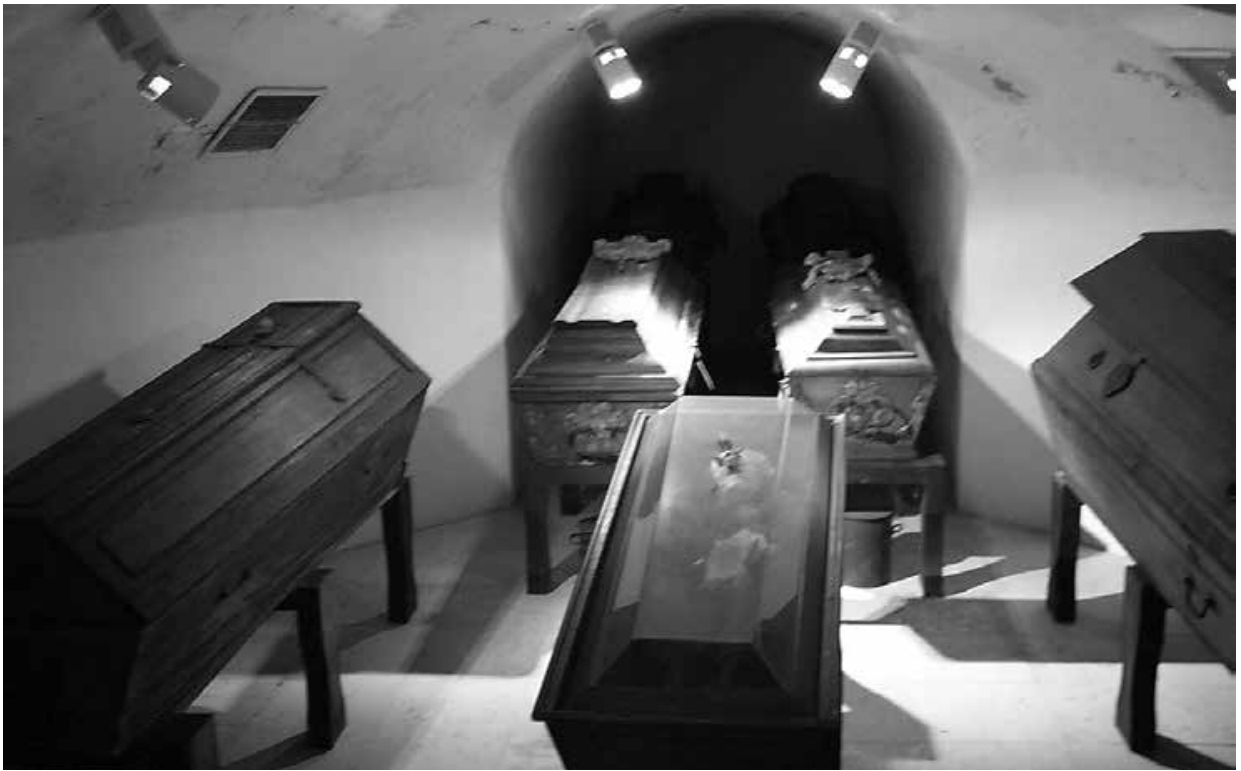

Obr. 19. Slavkov u Brna, pohřební kaple rodu Kouniců. Foto M. Králík.

Abb. 19. Slavkov bei Brno, Begräbniskapelle der Familie Kaunitz. Foto M. Králík. 


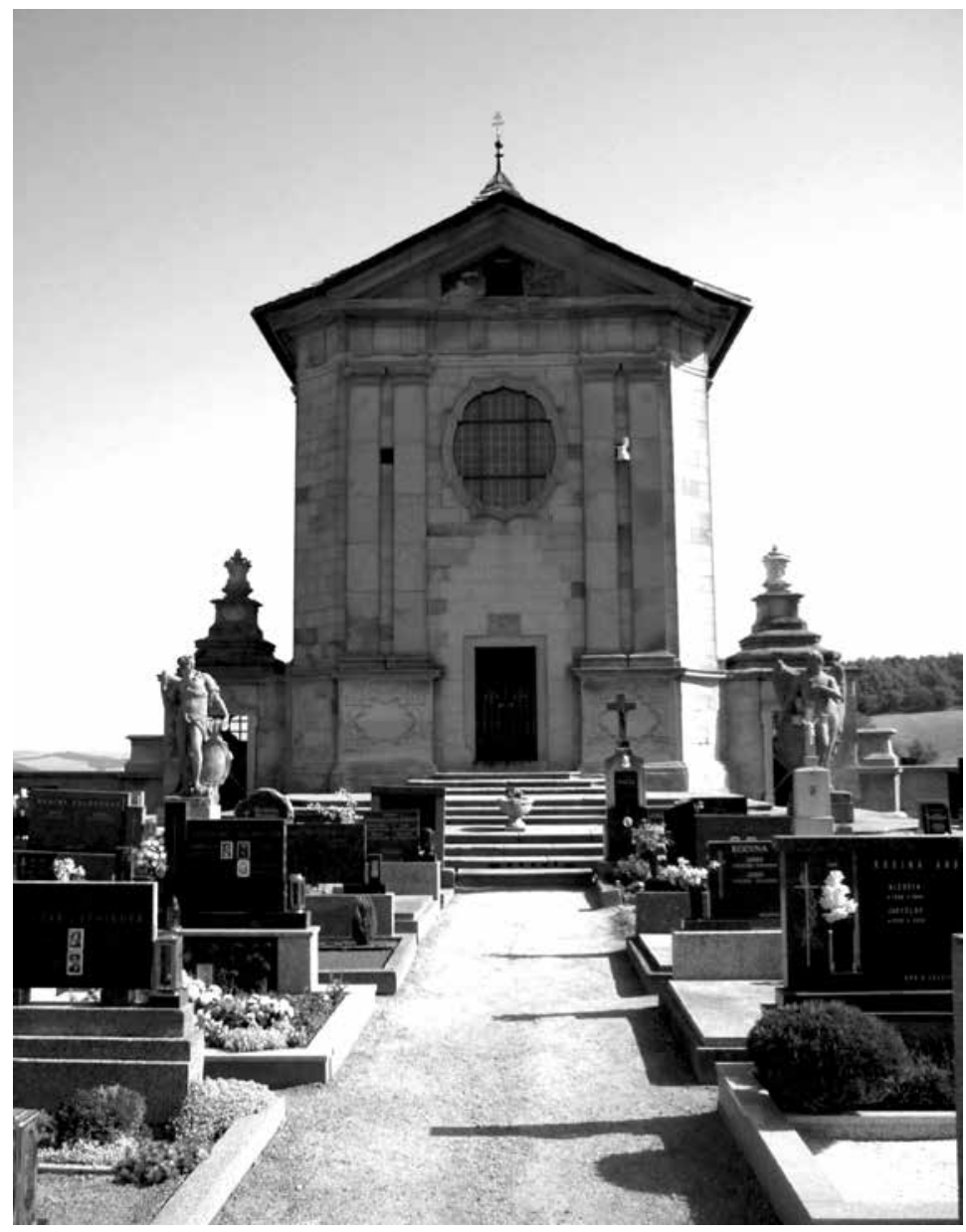

Obr. 20. Stř́lky, kaple s hrobkou Petřvaldských. Foto M. Králík.

Abb. 20. Stř́lky, Kapelle mit Gruft der Familie Petřvaldský. Foto M. Králík.

pozůstatky pohřebních oděvů a jejich doplňky (přezky, knoflíky, nášivky, spínadla atd.) včetně bot. Mimoto se setkáváme s poměrně bohatou osobní výbavou, a to především v 17.-18. století. Takové předměty byly kladeny zemřelým do hrobu záměrně jako výbava do záhrobí (souhrnně Králíková 2007, 133-157). Tato činnost souvisela s hlubším prožíváním smrti a posmrtného života. Mezi tyto předměty řadíme nástroje - železné předměty, řemeslnické a zemědělské náčiní (nože, nůžky, srpy apod.), předměty denní potřeby (fajfky, hřebínky, hračky, brýle apod.), dále mince. Ty mohou být považovány bud' za obolus, nebo se může jednat o osobní majetek, také mohly sloužit jako protivampyrické opatření. Záměrně byly do hrobu přidávány insignie (duchovní - kalich, pektorální kříže, prsteny; abatyšské - berle, korunky; panovnické a šlechtické - koruny, zbraně, odznaky hodností, řády, ostruhy - též vojenské). V hrobech zámožnějších jedinců najdeme šperky (prsteny, náušnice, spony a vlasové ozdoby - čelenky, jehlice apod.). Specifickým předmětem novověkých hrobů jsou věnečky splétané z kovových drátků. Nalezeny byly v hrobech dětí, adolescentů, mladých žen i kněží. Předpokládá se, že symbolizovaly nevinnost a čistotu zemřelých. 
Pro období 17.-18. století je zvláště typická devocionální výbava, která je spolehlivým chronologickým ukazatelem. Jedná se o předměty religiózní povahy, lidově svátostky (kř́íže, růžence, medailony, škapulíře, devoční grafika, drobné amuletky apod.), které jsou projevem žitého náboženství. V jejich symbolice se propojuje víra s pověrou. Byly běžně rozšířené a používané v každodenním životě, církví oficiálně tolerované, avšak nesoucí prvky pohanské pověrčivosti. Vkládaly důvěru do moci a schopností Panny Marie a velké řady svatých. Lidé od nich očekávali přímluvu a ochranu před všemi nástrahami světa, před zlou mocí, d'áblem, nemocemi ad. Kromě ochranné funkce byly medailony upomínkami na poutní místa, sloužily jako bratrské či jiné odznaky. Růžence a breviáře umožňovaly svému majiteli každodenní modlení. Latinské kř́žže a krucifixy byly symboly křest’anství, Ježíšova ukřrižování a jeho utrpení. Ostatní formy křiže (benediktinský, caravacový, Oldřichův a Zachariášův kříž) měly amuletovou ochrannou funkci. Ve většině př́ípadů se nejedná o předměty zvlášt' vysoké umělecké kvality, naopak často vykazují prvky sériové výroby. Byly tak běžně dostupné pro střední vrstvy obyvatelstva, městského i venkovského. Drobné křŕžky, medailonky a další svátostky byly zavěšovány na růžence, tyto se pak mrtvému omotávaly kolem zápěstí nebo předloktí, někdy se kladly do ruky (závěsný krŕžek). Větší dřevěné kříže s korpusem se mohly mrtvému pokládat na hrud' nebo se vkládaly do ruky. Obecně lze říci, že se devocionálie v hrobech nalézají povětšinou v úseku trupu až pánve. Objevují se v hrobech lidí všech věkových kategorií bez rozdílu pohlaví. Jednalo-li se tedy o řádného katolíka, jenž splnil podmínky smrti (nebyl „nečistý“ zemřelý) a prodělal předepsané pohřební úkony prováděné knězem, byl následně pohřben dle pravidel katolického ritu s náležitou výbavou.

\section{Závěr}

Jedním z důležitých ukazatelů charakterizujících určitou historickou kulturu je pohřební ritus obyvatelstva sledovaného období. Poměrně citlivě reaguje na náboženské, vojenské, zdravotní, hospodářské a jiné aspekty a události ve společnosti. V 16. století se projevuje nejednotnost $\mathrm{v}$ pohřbívání a oproti předchozímu i následujícímu období pokles $\mathrm{v}$ množství pohřební výbavy. V 17.-18. století můžeme v katolickém prostředí hovořit o jisté fascinaci smrtí, která byla patrná $\mathrm{v}$ bohatých a ve víre pevně zakotvených zvyklostech, v nákladnosti a teatrálnosti pohřebních obřadů a v neposlední řadě ve specifické pohřební výbavě religiózního charakteru. Varianty a odchylky v obřadech či ve volbě pohřebního místa se objevovaly v dobách epidemií, v obdobích konfliktů ve válečných oblastech, v sociálně si vzdálených společenských vrstvách (pohřby panovníků/vysokých hodnostářù vs. chudina), u jinověrců a odlišných etnických skupin. Zemřelí již nebyli pouhými anonymními jedinci, po smrti mnozí nebyli zapomenuti, nebot' jejich jména a životopisná data byla vytesána do náhrobních kamenů nebo zapsána do úmrtních matrik. Pozůstalí si je tak mohli častěji připomínat, což přetrvalo i do následujících období. Některé barokní zvyklosti se uplatňovaly ještě na počátku 19. století, zvláště ve vesnickém prostředí. Postupně se však smrt stává stále více privátní a v souvislosti s tím dochází i k obměnám v pohřbívání.

\section{Prameny a literatura}

ARIÈS, P., 2000: Dějiny smrti I, II. Praha.

BERKOVEC, T., 2002: Dlouhá Lhota (okr. Blansko), PV 43, 254-255.

BURIAN, V., 1972: Orientační průzkum Dietrichštejnské krypty pod Dómem sv. Václava v Olomouci, PV 1971, 126.

- 1992: Osudy tělesných pozůstatků olomouckého biskupa Františka kardinála z Dietrichštejna, VVM XLIV, 330-343.

CIMBU゚RKOVÁ, P., 2007: Přehled devocionálií nalezených při antropologickém výzkumu v kryptě kostela sv. Mikuláše ve Znojmě, JM 43, 183-211.

ČERNÁ, L. et al., 2012: Brno (okr. Brno-město), PV 53, č. 2, 100-131. 
ČIŽMÁř, Z., 2004: Znojmo (okr. Znojmo), PV 45, 249-250.

ČIŽMÁŘ, Z.-ŠMíD, M., 1999: Prostějov (okr. Prostějov), PV 40 (1997-1998), 363-369.

DAVID, P.-SOUKUP, V., 2002: 777 kostelů, klášterů, kaplí České republiky. Praha.

DĄBROWSKA, A., 1997: Liturgia śmierci a archeologia: Uwagi o wyborze miejsca pochowania, orientacji, ułożenia ciała i jego ubiorze w średniowiecznej Europie łacińskiej, Kwartalnik Historyczny 104, 3-14.

DESCOEUDRES, G.-CUENI, A.-HESSE, Ch.-KECK, G., 1995: Sterben in Schwyz. Basel.

DROZDOVÁ, E., 2006: Dietrichsteinové z Mikulova. Brno.

FALTÝNEK, K., 2000: Litovel (okr. Olomouc) - Kostel sv. Filipa a Jakuba. NZ č. j. 212/00, ulož. v archivu ARÚ AV ČR, Praha, v. v. i.

- 2000a: Záchranný archeologický výzkum v kapli sv. Jiří a v kostele sv. Marka v Litovli. Výroční zpráva Památkového ústavu v Olomouci 1999, 76-82. Olomouc.

FINGERLIN, I., 1992: Die Grafen von Sulz und ihr Begräbnis inTiengen am Hochrhein. Stuttgart.

HADRAVA, V. et al., 2014: Hadrava, V.-Kováčik, P.-Moskalíková, T.-Šlézar, P., Olomouc (k. ú. Olomouc-město, okr. Olomouc), PV 55, č. 2, 243.

HEJKAL, P.-HRUBÝ, P.-MRÁZ, V., 2004: Předběžné výsledky záchranných archeologických výzkumů v Jihlavě v roce 2003, PV 45, 101-102.

KAUEROVÁ, V.-KOUDELA, M., 1998: Památky staré Litovle. Olomouc.

KLANICOVÁ, E.-PEŠKA, J., 1993: Sondážní práce v tzv. Dietrichštejnské hrobce v Mikulově (okr. Břeclav), PV 1991, 80.

KOHOUTEK, J., 1999: Průzkum barokních krypt v kostele sv. Františka Xaverského a Zvěstování Panny Marie v Uherském Hradišti v roce 1998, Slovácko 41, 147-163.

KOS, P., 2004: Želešice (okr. Brno-venkov), PV 45, 251.

KOSTROUCH, F., 2011: Čejkovice (okr. Hodonín), PV 52, č. 2, 139-142.

KOVÁČIK, P.-HADRAVA, V., 2015: Olomouc (k. ú. Olomouc-město, okr. Olomouc), PV 56, č. 2, $295-297$.

KRÁL, A. B., 1969: Liechtensteinská hrobka na Vranově u Brna, VVM XXI, 121-131.

- 1969a: Nálezy ze Žerotínské hrobky v Židlochovicích, JM 5, 61-64.

- 1981: Žerotínská hrobka v Židlochovicích, JM 17, 329-332.

- 1984: Objev původního vstupu do Liechtensteinské hrobky na Vranově u Brna, VVM XXXVI, 69-72.

KRÁL, P., 2007: Knihy o dobrém umírání v českém prostředí ve druhé polovině 16. a první půli 17. století. In: Církev a smrt. Institucionalizace smrti v raném novověku (Holý, M.-Mikulec, J., edd.), 7-22. Praha.

KRÁLÍKOVÁ, M., 2007: Pohřební ritus 16.-18. století na území střední Evropy. Brno.

- 2012: Pohřbívání v brněnském kostele sv. Petra a Pavla v období 16. až 18. století, Pravěk NŘ 20, $271-324$.

KROUPA, J., 1986: Alchymie štěstí. Pozdní osvícenství a moravská společnost 1770-1810. Brno.

KRSEK, I. et al., 1996: Umění baroka na Moravě a ve Slezsku. Praha.

KUNC, F. J., 1937: Od počátku až do skonání světa. Praha.

LEHNER, M., 1996: Die Archäologie des Leechhügels, Fundberichte aus Österreich 35, 19-156.

MELZER, G., 1984: Archäologische Untersuchungen in der Pfarrkirche St. Martin zu Thalgau, Salzburg, Fundberichte aus Österreich 23, 37-59.

MIGLBAUER, R., 1991: Ausgrabungen im ehemaligen Minoritenkloster von Wels, Oberösterreich, Beiträge zur Mittelalter archäologie in Österreich 7, 93-113.

MIKULEC, J., 2007: Náboženská bratrstva - institucionalizovaná zbožnost i smrt. In: Církev a smrt. Institucionalizace smrti v raném novověku (Holý, M.-Mikulec, J., edd.), 163-186. Praha.

MLČÁK, L., 1984: Krypta pod kaplí sv. Antonína Paduánského u olomouckého kostela Neposkvrněného početí Panny Marie, VVM XXXVI, 344-346.

MORAVEC, Z. a kol., 2014: Moravec, Z.-Moravcová, I.-Živný, M.-Zedníková Malá, P., Př́iběh zapomenutého hřbitova. Ostrava.

NOVOTNÝ, B., 1967: Vyzvednutí pozůstatků maršála Raduita de Souches, obránce Brna proti Švédům, PV 1966, 56-57.

OBŠUSTA, P., 1999: Krhov (okr. Třebíč), PV 39 (1995-1996), 426.

ORLITA, Z., 2007: Pohřební průvod mezi pietou a sebereprezentací. In: Církev a smrt. Institucionalizace smrti v raném novověku (Holý, M.-Mikulec, J., edd.), 187-208. Praha.

PAVELČÍK, J., 1996: Uherské Hradiště - ul. Pod Rochusem. NZ, ulož. v archivu ARÚ AV ČR, Brno, v. v. i.

PRAHL, R. et al., 2004: Umění náhrobku v českých zemích let 1780-1830. Praha.

PRCHAL, J., 2002: Kostnice v Nížkově (okres Žd’ár nad Sázavou), Sborník Havlíčkobrodské společnosti pro povznesení regionálně historického povědomí 2, 34-35.

PROCHÁZKA, R.-ZATLOUKAL, R., 1991: Brno (okr. Brno-město) - Kostel sv. Tomáše. NZ, ulož. v Ústavu archeologické památkové péče, Brno. 
SCHRAM, W., 1896: Brünner Kirchengrüfte, Notizenblatte des Vereines für Geschichte Mährens und Schlesiens, 23-46.

SNÁŠIL, R., 1973: Zjištovací průzkum v Boršicích u Buchlovic, PV 1972, 62.

STERNECK, T., 2007: „Chtějí krchov, by pak třebas na několiko zámkuov zamčen byl, mocně odevř́íti a to mrtvé tělo sami pochovati“. Pohřby v konfesijně rozděleném prostředí na př́ikladu předbělohorského Brna. In: Církev a smrt. Institucionalizace smrti v raném novověku (Holý, M.-Mikulec, J., edd.), 79-113. Praha.

ŠENKY ŔIK, M., 1992: Historie chrámu Panny Marie ve Křtinách. Brno.

ŠIKULOVÁ, V., 1970: Krypta v moravské kapli kostela sv. Václava v Opavě, PV 1968, 67-69.

TIHELKA, K., 1950: Fundátoři Žarošské kaple v Bučovicích, VVM V, 64-68.

UNGER, J., 1997: Hroby z 15. a 16. století s nádobami dnem vzhůru na jižní Moravě. In: Život v archeologii středověku, 639-648. Praha.

- 2000: Pohřební ritus městského obyvatelstva 13. až 18. století v archeologických pramenech Moravy a Slezska - Der Grabritus der städtischen Bevölkerung im 13. bis 18. Jh. in archäologischen Quellen Mährens und Schlesiens, AH 25, 335-356.

- 2002: Pohřbívání v šestnáctém století, SPFFBU C 49, 41-48.

UNGER, J.-KOS, P., 2002: Znojmo (okr. Znojmo), PV 43, 306-308.

VÍTEJTE NA VYSOČINĚ. Kostnice, Nížkov, http://www.region-vysocina.cz/kostnice-cx1114, cit. 20.11. 2016.

VÍTEJTE NA VYSOČINĚ. Kostnice, Velká Losenice, http://www.region-vysocina.cz/kostnice-velka-losenice-cx29, cit. 20. 11. 2016.

ZATLOUKAL, R., 1999: Jihlava (okr. Jihlava), PV 39 (1995-1996), 417-418.

ZEMAN, T., 2015: Mohelnice (okr. Šumperk), PV 56, č. 2, 283-287.

ZEMANOVÁ-PETRŮ, R., 1973: Průzkum hrobky bývalého kapucínského kostela ve Vyškově, Vyškovský měsíčník 9, 10.

ZEZULA, M., 1999: Ostrava (okr. Ostrava), PV 40 (1997-1998), 354-358.

ZIMOLA, D., 2004: Jihlava (okr. Jihlava), PV 45, 200-202.

ZUBER, R., 1987: Osudy moravské církve v 18. století (1699-1777). Praha.

ZŮBEK, A., 2013: Hřbitov při kostele sv. Jakuba v Brně. Vyhodnocení archeologických poznatků. Disertační práce, Ústav archeologie a muzeologie, FF MU, Brno.

\section{Zusammenfassung}

\section{Bestattungen in Mähren im 16.-18. Jahrhundert}

In der Neuzeit wurden in Mähren Bestattungen nach bestimmten Regeln und Gebräuchen durchgeführt. Während im 16. Jahrhundert durch den Einfluss der instabilen Zeit mehrere alternative Bestattungen durchgeführt werden konnten, dies vor allem unter Andersgläubigen, hat sich im 17.-18. Jahrhundert bei den meisten sozialen Schichten vor allem der katholische Bestattungsritus durchgesetzt. Der Mensch der Neuzeit hat den Tod tief erlebt, er hat sich auf ihn vorbereitet und war bestrebt, ein solch gottesfürchtiges Leben zu führen, damit er die Bedingungen eines guten Todes erfüllte. Ein ordentlicher Katholik nahm vor dem Tod von seiner Familie Abschied, schrieb ein Testament und unterzog sich den von einem katholischen Priester durchgeführten nötigen Handlungen. All das führte dazu, dass er in der geweihten Erde eines Friedhofs begraben werden konnte. Sein Grab wurde ordentlich gekennzeichnet und mit den biographischen Daten versehen. Bedeutende Persönlichkeiten, weltliche und geistliche sowie sozial höhergestellte Individuen wurden mit der gebührenden Würde und mit Privilegien bestattet. Aus Prestigegründen waren ihre Bestattungen sehr kostspielig und pompös, und zwar vor allem in der Zeit des Barock, die auch von einer traditionellen Symbolik begleitet wurde. Der Verstorbene bekam eine persönliche Ausstattung mit ins Grab. Diese konnte aus Gegenständen des täglichen Bedarfs, aus Gerätschaften, Münzen und speziellen Attributen bestehen, durch welche die gesellschaftliche Funktion zum Ausdruck gebracht wurde, vor allem aber aus Gegenständen religiösen Charakters - Devotionalien (Rosenkränze, Medaillons, Kreuze u.ä.). Ein bestimmtes Privileg war eine Bestattung in einer Kirche. Die bedeutendsten nahmen dort die besten Plätze 
ein, d.h. so nah wie möglich am Chorraum oder an der Kirchenachse. Bestattet wurde auch in unterirdischen Krypten, für Familienbegräbnisse waren Kirchenkapellen beliebt. Neben Vertretern des Klerus und Ordensgeistlichen fanden dort auch Angehörige des Adels und reiche Bürger ihre letzte Ruhestätte. Im 18. Jahrhundert verbreiteten sich sowohl auf Friedhöfen, als auch auf privaten Grundstücken selbständige Bauten in Form von Kapellen als Bestattungsorte. Die Friedhöfe um städtische Kirchen füllten sich, und es mussten neue Bestattungsräume geschaffen werden. Skelettüberreste aus alten Gräbern und abgeschafften Friedhöfen wurden für gewöhnlich entweder in sich unter den Kirchen angelegten Ossarien oder in frei stehenden Beinhäusern aufbewahrt. Mit davon abweichenden Bestattungen werden beispielsweise Personen kenntlich gemacht, die unter besonderen Umständen gestorben waren (z.B. unreine Verstorbene) oder bei denen es sich um Straftäter und sonstige Personen vom Rande der Gesellschaft handelte. Solche Personen konnten beispielsweise außerhalb des Friedhofareals oder in einem Massengrab begraben werden, wobei ihre Körper eine dem Ritus nicht entsprechende Lage einnehmen konnte. In Massengräbern wurden auch vermögenslose Individuen, Soldaten oder bei einem Massensterben wie etwa Epidemien hingeschiedene bestattet. Auch trotz dieser anonymen Bestattungen hat man in der Neuzeit Bestattungen gegenüber der vorhergehenden Epoche besondere Bemühungen aufgewendet und Sorgfalt walten lassen. Obwohl sich Ende des 18. Jahrhunderts die Wahrnehmung des Todes allmählich änderte und immer privater wurde, werden einige Bestattungsgebräuche auch heute noch gepflegt, besonders in ländlicher Umgebung.

RNDr. Michaela Králíková, Ph.D., Muzeum Bučovice, detašované pracoviště Muzea Vyškovska, př́íspěvkové organizace, Zámek 1, 68501 Bučovice, Česká republika, kralikova@muzeum-vyskovska.cz 
